\title{
Undergraduate Perceptions of Economic Problems in Mexico
}

\author{
Russell McKenzie, Rajid Roberto Luna-Cruz, Elena Moreno-García and Aristides R. Baraya
}

\section{ABSTRACT}

Without question, changes in U.S. policies have impacts beyond its own borders. This work reports an analysis of how university students perceive Mexico's economic problems and their sources. The perceptions of younger Mexicans about economic problems are important, especially since young people represent $31 \%$ of Mexico's population. A survey developed by the National Survey GEA-ISA was administered to 200 students in May 2019. The results of this survey show that students believe that their family economy today is vulnerable and will not improve next year, and that the economic outlook last year was better than today. Results also indicate that improvements in macroeconomic variables alone are not enough to generate a perceived improvement in the Mexican economy.

Keywords: economic perceptions, economic conditions, higher education students, Mexico.

\section{INTRODUCTION}

With the election of President Donald Trump in the United States, the end of 2016 and the beginning of 2017 was especially volatile for the Mexican economy. Threats to revoke NAFTA, to build a wall along the border, to deport more immigrants and to increase taxes on remittances caused great uncertainty, pessimism and financial instability in Mexico. The persistence of low oil prices, the low dynamism of the external sector and the timid response of the domestic market conspired against the economic recovery [1]. In that context, in July 2018, Andrés Manuel López Obrador won the presidency of Mexico with more than $53 \%$ of the votes [2]. The Parametría [3] survey indicated that $55 \%$ of people between 18 and 25 years of age voted for the aforementioned candidate. With this level of support, it is easy to assume that this result leads to positive expectations among younger people regarding the potential achievements of the new federal administration.

In the last decade in Mexico, there has been an average of 23.15 million young adults, people between 18 and 29 years old. The Mexican government will have the challenge and the opportunity to offer health, education and employment services to this population that need to study, to work and to produce wealth [4]. The evolution of the economy and society will rely on the life experience of these young Mexicans and the influence of their perception of the economic situation over their decision making. insightful.
Published Online: January 9, 2021

ISSN: 2507-1076

DOI: $10.24018 /$ ejbmr.2021.6.1.679

Russell McKenzie *

Southeastern Louisiana University,

College of Business, USA.

(e-mail: russell.mckenzie ${ }^{\circledR}$ selu.edu)

Rajid Roberto Luna-Cruz

Universidad Cristóbal Colón, Campus

Calasanz, Carretera Veracruz-Medellín,

Col. Puente Moreno, México.

(e-mail: rajid.luna@ ${ }^{@}$ gmail.com)

Elena Moreno-García

Universidad Cristóbal Colón, Campus

Calasanz, Carretera Veracruz-Medellín,

Col. Puente Moreno, México.

(e-mail: elenam@ucc.mx)

Aristides R. Baraya

Southeastern Louisiana University,

College of Business, USA.

(e-mail: aristides.baraya ${ }^{\circledR}$ selu.edu)

*Corresponding Author

It is clear that when an economic crisis occurs, the perception of people becomes pessimistic and it generates in young people a negative feeling towards their government [5]. Otherwise, economic growth cause optimism and motivation in young people, as it happenend in India that reach an average rate of $7 \%$ of economic growth in the last 20 years [6]. People's main concerns when the global economic perspective turns complex are job insecurity and the decrease in purchasing power [7]. It is evident that during and after an economic crisis, young people are the most affected in terms of unemployment [8], [9].

Economic expectations are crucial for young adults because they may well make a difference between reaching career goals or floundering in the process [10]. These young adults represent more than $30 \%$ of Mexico's population. How they view economic conditions may influence many economic decisions. Thus, understanding their perceptions of Mexico's current economic conditions could be

\section{LITERATURE REVIEW}

Concha, Fix-Fierro, Flores and Valadés [11], carried out the work "Perception on the country's situation", where they aimed to learn how society perceived its current situation and the vision about its future. They applied two types of surveys to people over 15 years old; one sought to account for perceptions, attitudes, and values, as well as data related 
to their living conditions; and the second, focused on showing associations, descriptions, and definitions about the country's situation. Their findings indicated that $43 \%$ of respondents believe that the current situation in the country is "worse" than last year, coupled with $23 \%$ who think it is "equally bad". Age turned out to be an important factor. Approximately $31 \%$ of those between 15 and 19 years of age feel that the current situation in the country is "better", while $60 \%$ of those over 50 say the situation is "worse".

Aguiar, Omar, Soares, and Uribe [12] tried to explain expectations for the future among young students, as well as their main triggers. The study surveyed 922 middle and upper-level students in Argentine and Brazilian schools, asking about their expectations for the future. The results showed that a majority expected their future employment and professional conditions to be the same or worse than those at the time of the study.

Gómez, Pérez-Vacas and Sánchez [13] analyzed the perception of young university students about the labor market with the purpose of exploring the expectations they have about their future work in a crisis scenario. A total of 152 students from different careers, ranging from 22 to 26 years of age were interviewed using discussion groups, individual interviews, and open-ended questions. A qualitative analysis of the resulting information was completed. Among the results of this research, they showed that the vast majority of young people believe that the persistent economic crisis discourages job creation. They think that by emigrating they would find better working circumstances. They claim not to see the current economic crisis as a tragedy, since they are accustomed to severe economic problems, leading to an austere lifestyle.

Roesen [14] sought to identify the social impacts of the global economic crisis, analyzing how its effects affected the youth of Mozambique. Interviewing 284 people from 15 to 25 years of age in five cities, the study found that respondents perceive that there is a shortage of opportunities in general, but especially in the youth sector, and the government has been unable to generate the necessary jobs to reduce this impact. Factors such as crime and drugs are not associated with the causes of the economic crisis, but as a public security issue. This study also found that more than $53 \%$ believe that the conditions of the country are worse than the previous year.

Blizkovsky [15] assessed how university students in the European Union and Southeast Asia perceived the management of the crises that have arisen in those regions. Based on an opinion survey applied at four universities in 2012, the study found that most young people believe that the crisis in the EU has not been managed well, stating that the measures taken have not been effective. Regarding the Asian crisis, opinions were found to be more favorable. However, this is believed to be due to the lack of information on the subject since students know more about the EU crisis than the Asian one.

Pérez-Nievas [9] examined the impact of the economic crisis on discontent with the Spanish democracy. Analyzing data from before and after the crisis, the authors found that the younger population is the most affected in the economic crisis, with rising unemployment. This is most evident among those between ages 19 and 24, causing among other things, lower levels of citizen participation. The crisis generates social inequalities, which in turn become political discrepancies.

A study by Junankar [16] aimed to show the possible differences in the impact of the global financial crisis between young people and adults. Reviewing unemployment statistics for periods around the economic crisis revealed that the aftermath of the crisis generates higher unemployment rates among young people than among adults, even when the salary of the latter increases.

Similarly, Mortara [17] examined the perception of young people in a social and work context influenced by uncertainty of wages, job insecurity, and lack of confidence in the future. The study found that young people of higher cultural levels feel that their income and employment status is below that of past generations. Those of lower cultural levels look more compliant. They accept their current situation as they descend from families with economic problems and are more tolerant and more optimistic about the future.

Tsekeris [18] surveyed the perceptions of 253 Greek students between 18 and 30 years of age regarding the recent economic crisis, as well as their actions in response to it. The study determined that young people have a negative ideology and sense of failure, with $68 \%$ believing that the crisis does not allow them to plan for the future with any certainty and $43 \%$ of young people without a job having tried to leave the country. Young Greeks demand a better education system, more job opportunities, and a better quality of life.

United Nations Development Program [19] conducted a study exploring the socioeconomic perception of young people in Bosnia and Herzegovina. The objective of this research was to examine the attitudes and opinions of young people regarding employment and work, the economic, social, and political situations. This study revealed that young people are not satisfied with the situation and believe that the situation has not changed compared to two years ago. While they considered their standard of living average, they think that their quality of life is lower than that of their parents' generation. Moreover, they believe it to be deteriorating relative to the population.

Giugni and Grasso [20] analyzed the perception of the economic situation of European citizens from the perspective of the role that rulers play in economic crises, and the effects on political behavior. They examined data resulting from the financial crisis of 2008 and found that the people who blamed the government for the economic crisis and who were more dissatisfied with the way it managed unemployment had a greater vulnerability. In addition, the study concluded that such perceptions of political and economic conditions were complementary. Furthermore, one might expect the experiences of the crisis to vary according to its political and economic context [20], [21].

Giugni and Mexi [22] showed that the most disadvantaged segments of the Swiss population often have a stronger opinion of the crisis and the way the government has responded to it. The unemployed and lower income workers were more severely impacted by the economic crisis than other groups. As a result, these groups are more likely to hold pessimistic expectations regarding their future 
income.

The empirical evidence that has been addressed reflects that in general, in the face of an economic crisis, young people are the most affected, especially in terms of unemployment. In turn, the literary review makes it clear that in a scenario of economic crisis, young people show frustration, have the intention to change residence to another country, as well as the feeling of inefficiency in government decisions.

\section{Methodology AND Results}

Like a previous study conducted by the authors [23], this study employs an instrument developed by the National Survey GEA-ISA from 2008. The aim of the initial survey was to assess the perceptions of people regarding the effects that the 2008 financial crisis in the United States had on Mexico. The current study analyzes how university students in Mexico perceive Mexico's recent economic issues and its sources.

The authors administered the current survey in the summer of 2019 at the Business School of Universidad Cristóbal Colón in Veracruz, Mexico. Information was collected from 200 students, ranging in age from 18 to 26 years. The survey seeks to elicit the students' perceptions regarding current economic issues via a series of multiplechoice questions. In addition, it collects demographic information, degree program and the students' current classification to facilitate demographic segmentation. The following section presents the survey responses to the individual items in the survey.

The respondents' perceptions and tendencies are exposed through comparisons between groups and responses. Variable groupings are made in the following ways: perceptions regarding the current and expected future economic situation; family financial stability; macroeconomics; relative peso-dollar values; and affected economic sectors. The authors use Statistica V.19 software to analyze the information, collecting the means, standard deviations, minimum and maximum values, and relevant test statistics. These results are presented in the following tables. For all items in the survey, the Shapiro-Wilk and Lilliefors tests results indicate normal distributions for all items. That our data are normally distributed suggests validity of the results of the analysis.

Table 1 presents results of respondents' perceptions regarding the current economic conditions in Mexico and how the U.S. dollar impacts the Mexican economy. Item 1 shows that $89 \%$ of the students are very worried about the economic problems of the country. The rest of the students said they were less worried, but no one manifested as worryfree about Mexico's economic problems. Item 2 indicates that $69 \%$ of respondents believe that an economic recession would affect their family economy "a lot" (very much), while only $1 \%$ believe a recession will have no effect on their family.

TABLE 1: PERCEPTION ABOUT MEXICAN`S ECONOMIC PROBLEMS AND THE EFFECTS OF THE VALUE OF THE DOLLAR

\begin{tabular}{|c|c|c|c|c|c|c|c|c|c|c|c|c|}
\hline \multirow[b]{2}{*}{ Item } & \multirow[b]{2}{*}{ Question } & \multicolumn{4}{|c|}{ Option frequency } & \multirow[b]{2}{*}{$\begin{array}{c}\text { Min } \\
\text { value }\end{array}$} & \multirow[b]{2}{*}{$\begin{array}{c}\text { Max } \\
\text { Value }\end{array}$} & \multirow[b]{2}{*}{$\mu$} & \multirow[b]{2}{*}{ D.s. } & \multirow[b]{2}{*}{$\mathrm{P}<0.01$} & \multirow[b]{2}{*}{ SW-W } & \multirow[b]{2}{*}{ Lilliefors } \\
\hline & & $\begin{array}{l}\text { Very } \\
\text { much }\end{array}$ & Somewhat & $\begin{array}{l}\text { Not } \\
\text { at all }\end{array}$ & $\begin{array}{c}\text { Does not } \\
\text { know }\end{array}$ & & & & & & & \\
\hline 1 & $\begin{array}{l}\text { How worried are you about the } \\
\text { economic problems in Mexico? }\end{array}$ & $89 \%$ & $11 \%$ & $0 \%$ & $0 \%$ & 1 & 4 & 3.89 & .319 & $\mathrm{P}=0.00$ & .370 & $\mathrm{P}<0.01$ \\
\hline 2 & $\begin{array}{l}\text { How affected do you think you } \\
\text { and your family would be if } \\
\text { there were an economic } \\
\text { recession? }\end{array}$ & $69 \%$ & $20 \%$ & $1 \%$ & $10 \%$ & 1 & 4 & 3.48 & .929 & $\mathrm{P}=0.00$ & .600 & $\mathrm{P}<0.01$ \\
\hline 3 & $\begin{array}{l}\text { How much do you think the } \\
\text { current value of the dollar will } \\
\text { affect job creation in the } \\
\text { country? }\end{array}$ & $56 \%$ & $32 \%$ & $3 \%$ & $9 \%$ & 1 & 4 & 3.36 & .902 & $\mathrm{P}=0.00$ & .695 & $\mathrm{P}<0.01$ \\
\hline 4 & $\begin{array}{l}\text { How much do you think the } \\
\text { current value of the dollar will } \\
\text { affect Mexicans? } \\
\text { consumption capacity? }\end{array}$ & $71 \%$ & $27 \%$ & $1 \%$ & $1 \%$ & 1 & 4 & 3.67 & .559 & $\mathrm{P}=0.00$ & .596 & $\mathrm{P}<0.01$ \\
\hline 5 & $\begin{array}{l}\text { How much do you think the } \\
\text { current value of the dollar will } \\
\text { affect Mexican products sales } \\
\text { abroad? }\end{array}$ & $69 \%$ & $23 \%$ & $3 \%$ & $5 \%$ & 1 & 4 & 3.57 & .767 & $\mathrm{P}=0.00$ & .687 & $\mathrm{P}<0.01$ \\
\hline 6 & $\begin{array}{l}\text { How much do you think the } \\
\text { current value of the dollar will } \\
\text { affect the number of tourists that } \\
\text { visit Mexico? }\end{array}$ & $51 \%$ & $34 \%$ & $10 \%$ & $5 \%$ & 1 & 4 & 3.29 & .8554 & $\mathrm{P}=0.00$ & .763 & $\mathrm{P}<0.01$ \\
\hline 7 & $\begin{array}{l}\text { How much do you think the } \\
\text { current value of the dollar will } \\
\text { affect the country's income from } \\
\text { oil sale? }\end{array}$ & $66 \%$ & $21 \%$ & $4 \%$ & $9 \%$ & 1 & 4 & 3.44 & .9223 & $\mathrm{P}=0.00$ & .639 & $\mathrm{P}<0.01$ \\
\hline
\end{tabular}

Items 3 through 7 show that a significant majority believe that the value of the U.S. dollar has a significant impact on Mexico's economy is several ways. More than half of the participants $(56 \%)$ believe that the value of the dollar will significantly affect the creation of jobs in the country. A large percentage of students (71\%) think that the dollar's current value has a large impact on Mexicans' consumption capacity, while only $1 \%$ believe that it does not. A large majority (69\%) of those who responded expect that the current value of dollar will very much affect the sales of Mexican products in foreign markets. Only 3\% believe the current dollar price will not affect it. Item 6 indicates that $51 \%$ of those surveyed express concern that the dollar value will very much affect the number of tourists visiting Mexico, while item 7 shows that $66 \%$ believe that it will affect very much country's income from oil sales. Only 5\% 
believe it will not affect sales.

Table 2 reflects respondents' sentiments regarding the prospect of a recession in the next year and how it would impact Mexicans' jobs and consumption. According to participants' responses, most (53\%) think that the economy will suffer a recession next year. Items 9 and 10 show that $74 \%$ believe that people's jobs are not secure and $56 \%$ have significant concerns regarding the security of their family's consumption capacity.

Table 3 illustrates the students' perceptions of Mexico's current economic situation as it relates to past and expected future conditions. According to their responses, they are somewhat evenly split between the perceptions that the economy is "normal" (53\%) and "bad" (46\%). However, more than half $(53 \%)$ believe that the economic environment is worse than last year and $39 \%$ believe it will continue to worsen next year.

Table 4 presents the respondents' perceptions regarding prices, economic growth, income and purchasing power in Mexico. From the responses, it is clear that the students are somewhat pessimistic about the direction of the economy. Most pronounced is their expectations regarding inflation. This is highlighted with $68 \%$ expecting prices to increase more this year than last and $63 \%$ expecting even higher inflation next year. Across all items in Table 4, the students perceive a slowing economy that will have negative consequences for the overall economy and their families.

TABLE 2: PERCEPTION ABOUT MEXICAN FUTURE RECESSION, JOB AND FAMILY CONSUMPTION CAPACITY

\begin{tabular}{|c|c|c|c|c|c|c|c|c|c|c|c|}
\hline \multirow[b]{2}{*}{ Item } & \multirow[b]{2}{*}{ Question } & \multicolumn{3}{|c|}{ Option frequency } & \multirow[b]{2}{*}{$\begin{array}{c}\text { Min } \\
\text { value }\end{array}$} & \multirow[b]{2}{*}{$\begin{array}{c}\text { Max } \\
\text { value }\end{array}$} & \multirow[b]{2}{*}{$\mu$} & \multirow[b]{2}{*}{ D.s. } & \multirow[b]{2}{*}{$\mathrm{P}<0.01$} & \multirow[b]{2}{*}{ SW-W } & \multirow[b]{2}{*}{ Lilliefors } \\
\hline & & Yes & No & $\begin{array}{l}\text { Does not } \\
\text { know }\end{array}$ & & & & & & & \\
\hline 8 & $\begin{array}{l}\text { Do you think there will be a recession in } \\
\text { Mexico next year? }\end{array}$ & $53 \%$ & $14 \%$ & $33 \%$ & 0 & 2 & 1.21 & .904 & $\mathrm{P}=0.00$ & .706 & $\mathrm{P}<0.01$ \\
\hline 9 & $\begin{array}{l}\text { Do you think the jobs of those who live } \\
\text { and work here are secure? }\end{array}$ & $11 \%$ & $74 \%$ & $15 \%$ & 0 & 2 & 0.97 & .515 & $\mathrm{P}=0.00$ & .692 & $\mathrm{P}<0.01$ \\
\hline 10 & $\begin{array}{l}\text { Do you think your family's consumption } \\
\text { capacity is secure? }\end{array}$ & $27 \%$ & $56 \%$ & $17 \%$ & 0 & 2 & 1.11 & .660 & $\mathrm{P}=0.00$ & .793 & $\mathrm{P}<0.01$ \\
\hline
\end{tabular}

TABLE 3: MEXICAN ECONOMIC SITUATION COMPAREd LAST YEAR AND FORECASTING THE NeXT YEAR

\begin{tabular}{|c|c|c|c|c|c|c|c|c|c|c|c|c|}
\hline \multirow[b]{2}{*}{$\begin{array}{l}\text { Ite } \\
\mathrm{m}\end{array}$} & \multirow[b]{2}{*}{ Question } & \multicolumn{4}{|c|}{ Option frequency } & \multirow[b]{2}{*}{$\begin{array}{c}\text { Min } \\
\text { value }\end{array}$} & \multirow[b]{2}{*}{$\begin{array}{c}\text { Max } \\
\text { Value }\end{array}$} & \multirow[b]{2}{*}{$\mu$} & \multirow[b]{2}{*}{ D.s. } & \multirow[b]{2}{*}{$P<0.01$} & \multirow[b]{2}{*}{ SW-W } & \multirow[b]{2}{*}{ Lilliefors } \\
\hline & & $\begin{array}{l}\text { Good / } \\
\text { Better }\end{array}$ & $\begin{array}{l}\text { Normal / } \\
\text { The same }\end{array}$ & $\begin{array}{c}\text { Bad / } \\
\text { Worse }\end{array}$ & $\begin{array}{c}\text { Does not } \\
\text { know }\end{array}$ & & & & & & & \\
\hline 11 & $\begin{array}{l}\text { In general, how do you consider } \\
\text { the country's current economic } \\
\text { situation? }\end{array}$ & $1 \%$ & $53 \%$ & $46 \%$ & $0 \%$ & 1 & 4 & 2.55 & .509 & $\mathrm{P}=0.00$ & .657 & $\mathrm{P}<0.01$ \\
\hline 12 & $\begin{array}{l}\text { What grade would you give to } \\
\text { the country's current economic } \\
\text { situation compared to that of last } \\
\text { year? }\end{array}$ & $3 \%$ & $40 \%$ & $53 \%$ & $4 \%$ & 1 & 4 & 2.43 & .630 & $\mathrm{P}=0.00$ & .786 & $\mathrm{P}<0.01$ \\
\hline 13 & $\begin{array}{l}\text { How do you think the country's } \\
\text { economic situation will be next } \\
\text { year compared to this year's? }\end{array}$ & $12 \%$ & $30 \%$ & $39 \%$ & $19 \%$ & 1 & 4 & 2.37 & .936 & $\mathrm{P}=0.00$ & .877 & $\mathrm{P}<0.01$ \\
\hline
\end{tabular}

TABLE 4: PERCEPTION ABOUt PRICES, ECONOMIC Growth, INCOME AND PURCHASING POWER IN MEXICO

\begin{tabular}{|c|c|c|c|c|c|c|c|c|c|c|c|c|}
\hline \multirow[b]{2}{*}{ Item } & \multirow[b]{2}{*}{ Question } & \multicolumn{4}{|c|}{ Option frequency } & \multirow[b]{2}{*}{$\begin{array}{c}\text { Min } \\
\text { value }\end{array}$} & \multirow[b]{2}{*}{$\begin{array}{c}\text { Max } \\
\text { Value }\end{array}$} & \multirow[b]{2}{*}{$\mu$} & \multirow[b]{2}{*}{ D.s. } & \multirow[b]{2}{*}{$\mathrm{P}<0.01$} & \multirow[b]{2}{*}{ SW-W } & \multirow[b]{2}{*}{ Lilliefors } \\
\hline & & Higher & $\begin{array}{l}\text { The } \\
\text { same }\end{array}$ & Less & $\begin{array}{c}\text { Does not } \\
\text { know }\end{array}$ & & & & & & & \\
\hline 14 & $\begin{array}{l}\text { Compared to last year, how do } \\
\text { you think price increase will be } \\
\text { this year? }\end{array}$ & $68 \%$ & $24 \%$ & $5 \%$ & $3 \%$ & 1 & 4 & 3.56 & .734 & $\mathrm{P}=0.00$ & .635 & $\mathrm{P}<0.01$ \\
\hline 15 & $\begin{array}{l}\text { Compared to last year, how do } \\
\text { you think this year's economic } \\
\text { growth will be? }\end{array}$ & $5 \%$ & $38 \%$ & $52 \%$ & $5 \%$ & 1 & 4 & 2.45 & .685 & $\mathrm{P}=0.00$ & .812 & $\mathrm{P}<0.01$ \\
\hline 16 & $\begin{array}{l}\text { Compared to this year, how do } \\
\text { you think the price increase will } \\
\text { be next year? }\end{array}$ & $63 \%$ & $23 \%$ & $8 \%$ & $6 \%$ & 1 & 4 & 3.42 & .887 & $\mathrm{P}=0.00$ & .683 & $\mathrm{P}<0.01$ \\
\hline 17 & $\begin{array}{l}\text { Compared to this year, how do } \\
\text { you think next year's economic } \\
\text { growth will be? }\end{array}$ & $12 \%$ & $44 \%$ & $37 \%$ & $7 \%$ & 1 & 4 & 2.63 & .792 & $\mathrm{P}=0.00$ & .860 & $\mathrm{P}<0.01$ \\
\hline 18 & $\begin{array}{l}\text { How do you think your family } \\
\text { income will be next year? }\end{array}$ & $12 \%$ & $48 \%$ & $20 \%$ & $20 \%$ & 1 & 4 & 2.53 & .951 & $\mathrm{P}=0.00$ & .845 & $\mathrm{P}<0.01$ \\
\hline 19 & $\begin{array}{l}\text { How do you think your } \\
\text { purchasing power will be next } \\
\text { year? }\end{array}$ & $14 \%$ & $28 \%$ & $38 \%$ & $20 \%$ & 1 & 4 & 2.36 & .957 & $\mathrm{P}=0.00$ & .876 & $\mathrm{P}<0.01$ \\
\hline
\end{tabular}

TABLE 5: PERCEPTION ABOUT THE MAIN PROBLEMS IN MeXiCO

\begin{tabular}{|c|c|c|c|c|c|c|c|c|c|c|}
\hline Item & Question & Option & Frequency & $\begin{array}{c}\text { Min } \\
\text { value }\end{array}$ & $\begin{array}{l}\text { Max } \\
\text { value }\end{array}$ & $\mu$ & D.s. & $\mathrm{P}<0.01$ & SW-W & Lilliefors \\
\hline 20 & $\begin{array}{l}\text { Which do you think is } \\
\text { currently the country's } \\
\text { main problem? }\end{array}$ & $\begin{array}{l}\text { Economy } \\
\text { Politics } \\
\text { Security } \\
\text { Services } \\
\text { Others } \\
\text { None } \\
\text { Does not know }\end{array}$ & $\begin{array}{c}23 \% \\
48 \% \\
21 \% \\
1 \% \\
6 \% \\
0 \% \\
1 \% \\
\end{array}$ & 1 & 7 & 5.79 & 1.051 & $\mathrm{P}=0.00$ & .803 & $\mathrm{P}<0.01$ \\
\hline
\end{tabular}


Item 20 in Table 5 solicits the students' perceptions as to what is the main concern or problem that affects Mexico. Politics is perceived to be the main problem according to the findings, with a convincing $48 \%$ citing this as the primary problem. The respondents perceive the economy (23\%) and security $(21 \%)$ as secondary problems.

\section{DISCUSSION}

The economic expectations of young adults are significant because they can make a difference between achieving career goals or not [10]. This study's results illustrate the expectations of university students in Mexico toward the country's economic situation. It is insightful to compare results of this research with the findings of other studies.

Aguiar, Omar, Soares y Uribe [12] found that $67 \%$ of young people from Argentina and Brazil believe that their future employment situations will likely be no better than the present. This study indicates that $74 \%$ of students interviewed believe that employment for those who live and work here is not secure.

According to the United Nations Development Programme [19], young people from Bosnia and Herzegovina are not satisfied with the political, economic and social situation, and believe it has not improved. The Mexican students interviewed also seem to be dissatisfied with the situation, since $89 \%$ said they were very concerned about Mexico's economic problems, $46 \%$ believe that current economic situation in Mexico is bad, and 53\% believe that there will be an economic recession in Mexico next year. Even $53 \%$ of young people surveyed think that the country's current economic situation is worse than last year.

Tsekeris [18] talks about a negative ideology in Greek young people resulting from an economic crisis. This study shows that $52 \%$ of young people believe that this year's economic growth will be lower than last year, and $44 \%$ expect nest year's economic growth to be the same as the current year.

Mortara [17] argues that Italian young people point out that beyond economic issues, there is a crisis of values that generates greater conflicts for society. Coincidentally, $48 \%$ of university students in this analysis feel that country's main problem is political versus $23 \%$ who cited economic concerns as the biggest problem.

Giugni and Mexi [22] point out that when facing an economic crisis, people are more likely to be pessimistic about their future financial situation. In this research, results show that only $14 \%$ of young people believe that their purchasing power will be higher next year. Only $12 \%$ expect their family income to be higher the following year, and $63 \%$ believe that prices will increase next year.

Finally, it would be interesting to research more about student understanding of the effects of dollar exchange rate changes on the Mexican economy. In questions about how dollar values affect the Mexican economy, most students responded "very much". They believe that the dollar value has very significant effects on Mexico's job creation, consumption capacity, product sales abroad, and the country's income from the sale of oil, as well as the number of tourists visiting Mexico. It is not clear if the great affectation they express is understood correctly. It raises the question of whether they are aware that dollar appreciation tends to increase tourism, product exports, and income from oil sales, or if the "very much" answers are simply a reflection of their overall pessimism.

Results of this research shows that university students in Mexico not only have a negative perspective regarding the current economic situation in the country, but also that they expect conditions to worsen. Young people believe that their family economy will not improve next year, that last year the economic outlook was better, and that the current macroeconomic factors are not enough to generate economic growth. Given the relative size of this demographic in Mexico, these results should positively inform relevant policymakers going forward. Whether the perceptions exposed through this study reflect reality or not, it is precisely these perceptions that influence economic behavior, and thus should influence national economic policies.

\section{REFERENCES}

[1] Cárdenas, E. (2018). Mexican Fiscal Policy during Peña Nieto's Administration (2013-2017). A First Assesment. El Trimestre Económico, vol. LXXXV (4), núm. 340, octubre-diciembre, 887-923. doi: $10.20430 /$ ete.v85i340.764.

[2] Instituto Nacional Electoral (2018). Resultados electorales. Cómputos distritales. Resultados de escrutinio y cómputo. Retrieved from: https://computos2018.ine.mx/\#/presidencia/nacional/1/1/1/1.

[3] Parametría (2018). Carta Paramétrica. ¿Quiénes eligieron a AMLO como presidente? Retrieved http://www.parametria.com.mx/carta_parametrica.php?cp=5053.

[4] Murayama, C. (2010). Juventud y crisis: ¿hacia una generación perdida?. Economía-UNAM. Retrieved from http://www.ejournal.unam.mx/ecu/ ecunam20/ ECU002000704.pdf.

[5] Rosser, A., Suriá, R. y Villegas, E. (2013). Diferencias en actitudes y expectativas de futuro laboral antes y después de haber iniciado $\begin{array}{llll}\text { estudios universitarios. } & \text { Retrieved }\end{array}$ http://web.ua.es/es/ice/jornadas-redes/documentos/2013comunicaciones-orales/334594.pdf.

[6] Kapoor, R. (2014). La era del optimismo: desenredando las perspectivas de futuro de los jóvenes indios. Revista de Estudios de Juventud, núm. 104, marzo 109-119.

[7] Benitez, I. y Vivas, E. (2007). La juventud española y su percepción de la globalización neoliberal y del movimiento altermundista, Revista de Estudios de Juventud, Marzo 07, no. 76 163-180.

[8] Verick, S. (2010). Who is hit hardest during a financial crisis? The vulnerability of Young men and women to unemployment in a economic downturn. Iyanatul Islam and Sher Verick (eds.), From the Great Recession to Labour Market Recovery: Issues, Evidence and Policy Options, Basingstoke, Hampshire, UK; ILO/Palgrave Macmillan, pp 1-35.

[9] Pérez-Nievas, S. (2013). Los efectos de la crisis económica en la democracia española: legitimidad, insatisfacción y desafección. Proyecto de Investigación del Departamento de Ciencia Política y Relaciones Internacionales, Universidad Autónoma de Madrid, 1-203.

[10] Bandelj, N. and Lanuza, Y. (2018). Economic Expectations of Young Adults. Socius: Sociological Research for a Dynamic World, Volume 4 1-23.

[11] Concha, H., Fix-Fierro, H., Flores, J. y Valadés, D. (2004). Percepciones sobre la situación del país. Cultura de la constitución en México. Una encuesta de actitudes, percepciones y valores. III. Biblioteca Jurídica Virtual, UNAM 7-15.

[12] Aguiar, M., Omar, A., Soares, N., y Uribe, H. (2005). Perspectivas de futuro y búsqueda de sensaciones en jóvenes estudiantes. Un estudio entre Argentina y Brasil. Revista Latinoamericana de Estudios Educativos, vol. XXXV, núm. 1-2, 1ero-2do trimestres, pp 165-180.

[13] Gómez, M., Pérez-Vacas, C. y Sánchez, S. (2009). Percepción del mercado laboral de jóvenes estudiantes universitarios: una aproximación cualitativa. INFAD Revista de Psicología, International Journal of Developmental and Educational Psychology, núm. 4, 221229. 
[14] Roesen, G. (2011). Youth vulnerabilities to economic shocks: A case study of the social impact of the global economic crisis on youth in four neighborhoods in Maputo city, Mozambique. Overseas Development Institute, marzo, 1-30.

[15] Blizkovsky, P. (2012). Students'cross-perception of the economic crises in the European Union and in Southeast Asia. EU Centre in Singapore Working Paper No. 11, December. 1-17.

[16] Junankar, R. (2014). The impact of the global financial crisis on youth labour market. IZA Discussion Paper No. 8400, agosto, 1-32.

[17] Mortara, Ariela (2015). The impact of the economic crisis on Italian young people's everyday life Sociologia, Revista da Faculdade de Letras da Universidade do Porto Número temático - Práticas de consumo: valores e orientações, 2015, 93-112.

[18] Tsekeris, Ch. (2015). Young people's perception of economic crisis in contemporary Greece: a social psychological pilot study. Crisis Observatory Research Paper, núm. 19, noviembre 1-25.

[19] UNDP (2017) BiH-activity under the Global Project, Building and consolidating Capacities for Conflict Prevention, funded by the European Union (EU) and implemented by the United Nations Development Programme (UNDP) in Bosnia and Herzegovina.

[20] Giugni, M., \& Grasso, M. T. (2017). Blame and Contention: How Perceptions of the Government's Role in the Economic Crisis Shape Patterns of Political Action. Acta Politica (Open Access). Retrieved from https://link.springer. com/article/10.1057\%2Fs41269-017-0073$\mathrm{x}$.

[21] Giugni M. and Grasso M. (2018). Citizens and the Crisis: Perceptions, Experiences, and Responses to the Great Recession in Nine Democracies. In: Giugni M., Grasso M. (eds) Citizens and the Crisis. Palgrave Studies in European Political Sociology. Palgrave Macmillan, Cham.

[22] Giugni, M. and Mexi, M. (2018). The Silent Crisis: Perceptions and Experiences of the Economic Crisis in Switzerland. Citizens and the Crisis, 215-238. doi:10.1007/978-3-319-68960-9_9.

[23] Moreno Aguiar, E., Garcia Santillan A., Luna Cruz, R., and Gonzalez Gomez, S. (2018). Economic Problems in Mexico: As Perceived by Students. Economics \& Sociology, 11(2), 157-172.

Dr. Russell McKenzie is Associate Professor of Economics at Southeastern Louisiana University. He earned a Ph.D. in Economics from Oklahoma State University and Master's in Economic Development from the University of Southern Mississippi. His research interests include economics education, real estate economics and international relations.

Rajid R. Luna is completing a Ph.D. in Law, Government and Public Policy at the Universidad Autónoma de Madrid. He obtained a Master's degree in Political Science at Universidad Autónoma de Nuevo León and a Bachelor of Economics at Universidad Cristóbal Colón, Veracruz, Mexico.

Dr. Elena Moreno-Garcia is researcher and teaches undergraduate and postgraduate economics and finance at Universidad Cristóbal Colón, Mexico. She is highly ranked in the Mexican National Research System (SNI, 2). Dr. Moreno-Garcia obtained a Ph.D. in Economics at Almería University, Spain. She earned a Master's degree in Finance at Universidad de las Américas in Puebla, Mexico and a Bachelor of Economics at Universidad Cristóbal Colón, Veracruz, Mexico. Her research interests are financial education, perception about economic and financial situation and anxiety towards mathematics.

Dr. Aristides R. Baraya is the Director of the Latin American Business Development Initiative at Southeastern Louisiana University. His research interest includes youth entrepreneur, international management, Hispanic advances and leadership. 